\title{
The Role of Matrix Metalloproteinases in Endometriosis: A Potential Target
}

\author{
Junya Ke ${ }^{1,2,3}$, Jiangfeng Ye ${ }^{4}$, Mingqing $\mathrm{Li}^{1,3,5, * \mathbb{D}}$ and Zhiling Zhu ${ }^{1,2, *}$ \\ 1 Department of Obstetrics and Gynecology, Obstetrics and Gynecology Hospital of Fudan University, \\ Shanghai 200011, China; 17211250006@fudan.edu.cn \\ 2 Department of Integrated Traditional \& Western Medicine, Obstetrics and Gynecology Hospital of Fudan \\ University, Shanghai 200011, China \\ 3 Institute of Obstetrics and Gynecology, Obstetrics and Gynecology Hospital of Fudan University, \\ Shanghai 200011, China \\ 4 Division of Obstetrics and Gynecology, KK Women's and Children's Hospital, Singapore 229899, Singapore; \\ ye.jiangfeng@kkh.com.sg \\ 5 Shanghai Key Laboratory of Female Reproductive Endocrine-Related Diseases, Shanghai 200011, China \\ * Correspondence: mqli@fudan.edu.cn (M.L.); zhuzhiling1023@fckyy.org.cn (Z.Z.); \\ Tel./Fax: +86-21-3318-9900-6420 (Z.Z.)
}

Citation: Ke, J.; Ye, J.; Li, M.; Zhu, Z. The Role of Matrix

Metalloproteinases in Endometriosis: A Potential Target. Biomolecules 2021, 11, 1739. https://doi.org/10.3390/ biom11111739

\section{Academic Editors:}

Giuseppe Benagiano

and Haengseok Song

Received: 11 October 2021

Accepted: 19 November 2021

Published: 22 November 2021

Publisher's Note: MDPI stays neutral with regard to jurisdictional claims in published maps and institutional affiliations.

Copyright: (c) 2021 by the authors. Licensee MDPI, Basel, Switzerland. This article is an open access article distributed under the terms and conditions of the Creative Commons Attribution (CC BY) license (https:// creativecommons.org/licenses/by/ $4.0 /)$.

\begin{abstract}
Endometriosis is a condition that is influenced by hormones and involves stroma and glands being found outside the uterus; there are increases in proliferation, invasion, internal bleeding, and fibrosis. Matrix metalloproteinases (MMPs) have been suggested to be crucial in the progression of invasion. The MMP family includes calcium-dependent zinc-containing endopeptidases, some of which not only affect the process of cell invasion but also participate in other physiological and pathological processes, such as angiogenesis and fibrosis. MMPs act as downstream-targeted molecules and their expression can be regulated by numerous factors such as estrogen, oxidative stress, cytokines, and environmental contaminants. Given their unique roles in endometriosis, MMPs may become effective biomarkers of endometriosis in the future. In the present review, we summarize the current literature on MMPs regarding their classification, function, and potential value for endometriosis, which may contribute to our knowledge of MMPs and MMP-targeted interventions.
\end{abstract}

Keywords: matrix metalloproteinases; endometriosis; function; potential value

\section{Introduction}

Endometriosis is a benign, hormone-dependent disease characterized by the presence of endometrial glands and stroma outside the uterus and affects at least $10-15 \%$ of women of reproductive age [1]. Several characteristics, such as infertility, dysmenorrhea, and dyspareunia, are associated with endometriosis [2]. Moreover, estrogen, matrix remodeling, inflammation, and oxidative stress have been shown to be involved in endometriosis progression from early to advanced stages [3].

Based on the hypothesis of the retrograde transplantation theory proposed by Sampson in 1927, we recognize the significance of matrix regrading and matrix remolding. Endometriosis is established when endometrial cells (influenced by hormone fluctuations) break off and travel via the fallopian tubes to new sites, where they implant and grow. The extracellular matrix (ECM) is a complex network of macromolecular structures, such as collagens, proteoglycans, glycoproteins, and elastin [4]. The matrix metalloprotease (MMP) family is devoted to maintaining ECM homeostasis, and the dysregulation of its expression leads to the disease. Since the 1960s, the MMP family has drawn much attention, and its functions have been further determined [5] and systematically reviewed. [6].

In this review, we propose a role for MMPs in endometriosis and describe their different functions in various biological processes, such as invasion, angiogenesis, and fibrosis. 
More importantly, we further discuss the potential treatment options for endometriosis, especially anti-MMP interventions.

\section{The MMP Family}

MMPs belong to a large family of calcium-dependent, zinc-containing endopeptidases that are known for their ability to cleave nonmatrix proteins, as well as several ECM constituents (e.g., collagens, proteoglycan, and glycoproteins). In 1949, MMPs were discovered to be depolymerizing enzymes that could promote the proliferation of malignant cells by remolding connective tissue stroma such as blood vessels [7]. A decade later, the first vertebrate MMP was isolated and identified to act as a collagenase [5]. At least $28 \mathrm{MMPs}$ have been identified in mammals to date [8].

\subsection{Classification of $M M P S$}

How MMPs should be classified remains controversial. A previous report classified them into the following five groups based on their substrate-specificity and location: collagenases, gelatinases, stromelysins, matrilysins, and membrane-type metalloproteinases [9]. However, Garcia-Fernandez et al. and Kapoor et al. both divided MMPs into six groups depending on their different substrates. Compared with the previous five groups, the latter researchers added an "other MMPs" group, which included those that did not fit into any other category $[7,10]$. Beyond that, MMPs can also be divided into two groups: secreted MMPs and anchor MMPs. Of the known MMPs, MMP14, 15, 16, 17, 23, 24, and 25 are membrane-anchored [11,12].

\subsection{Structure of $M M P s$}

The sophisticated structure of MMPs has been known for some time and has been described in significant detail [13]. The compositions of most MMPs are the same: they involve a pro-peptide domain, a signal peptide, a cysteine switch motif, a catalytic domain, and a hemopexin-like domain [7]. However, some MMPs have different structural characteristics that enable them to perform special activities. For example, MMP2 and MMP9 can interact with collagen via three fibronectin type-II domains. Moreover, MMP7, MMP23, and MMP26 have no C-terminal hemopexin-like domain, which usually consists of 190 amino acids. Additionally, MMP23 is the only MMP that possesses a cysteine-rich and Ig domain. Some researchers have designed MMP inhibitors according to the specific structures. Ilomastat (GM-6001), a first-generation collagen peptidomimetic, is a broadspectrum MMP inhibitor [14,15]. However, due to its poor bioavailability, clinical trials of ilomastat have failed. However, Tanomastat (BAY 12-9566) has been shown to potently and selectively inhibit MMP13, gelatinase A, and gelatinase B. It is an analog of biphenyl nonpeptide butanoic acid and was first developed by Bayer, Inc. (Leverkusen, Germany) [16]. However, no anti-MMP inhibitors with few side effects and strong specificity have been used in clinical anti-tumor therapy to date.

\subsection{The Expression of MMPs (Natural MMP Inhibitors)}

MMPs are generally poorly expressed in humans due to their specific endogenous inhibitors, known as the tissue inhibitor of metalloproteinase (TIMP) family, which includes four known proteins: TIMP-1, 2, 3, and 4 [17]. TIMPs can bind to the catalytic domains of MMPs with a 1:1 stoichiometric ratio and then block their enzymatic activity [18,19]. The TIMP family includes proteins with specific substrates; for example, TIMP-1 can only regulate the membrane-type MMPs, but the other three members have wider ranges of biological activity [9]. In addition to MMPs, TIMPs can suppress other enzymes, such as those of the disintegrin and metalloproteinase (ADAM) family [20-22]. 


\section{MMP Expression in Endometriosis}

\subsection{Summary of Clinical Studies}

Aside from MMP7, which is only expressed in epithelial endometrial cells, MMPs are present in both the stromal and epithelial tissue compartments of the endometrium [23]. As an invasive disorder, endometriosis involves increased MMP activity. Several studies have reported that the levels of MMPs are elevated in the ectopic tissue, peritoneal fluid, or sera of patients with endometriosis, especially MMP2 and MMP9 [24-26]. In addition, Borghese et al. shared gene expression profiles of eutopic. vs. ectopic endometrium in 2008 and provided a list of more than 5600 genes related to endometriosis. The overexpressed extracellular matrix genes (such as MMP23 and MMP26) showed significant expression differences [27]. However, the potential mechanism of the dysregulation of MMP23 and MMP26 expression still needs further research. Considering their key roles in endometriosis, MMPs have been considered potential therapeutic targets for this disease. As presented in Table 1, accumulating evidence has demonstrated that MMPs play significant roles in promoting the development of endometriosis.

Table 1. Changes in MMPs in endometriosis.

\begin{tabular}{|c|c|c|c|c|}
\hline Classification & MMPs & Location & $\begin{array}{c}\text { Change } \\
\text { (Endometriosis. vs. } \\
\text { Control) }\end{array}$ & Reference \\
\hline \multirow{5}{*}{ Collagenases } & \multirow{2}{*}{ MMP1 } & Eutopic endometrium & up & [28] \\
\hline & & Peripheral blood & down & [29] \\
\hline & \multirow{2}{*}{ MMP13 } & Ectopic endometrium & up & [30] \\
\hline & & Peritoneal fluid & down & [31] \\
\hline & & & up & {$[24,32-35]$} \\
\hline \multirow{8}{*}{ Gelatinases } & \multirow{5}{*}{ MMP2 } & Ectopic endometrium & up & [36] \\
\hline & & Eutopic endometrium & down & [37] \\
\hline & & Peripheral blood & ns & {$[25,34]$} \\
\hline & & Peritoneal fluid & up & {$[24,38]$} \\
\hline & & & up & {$[24,38]$} \\
\hline & \multirow{3}{*}{ MMP9 } & Ectopic endometrium & up & {$[32,33,39]$} \\
\hline & & $\begin{array}{l}\text { Ectopic enaometrium } \\
\text { Eutopic endometrium }\end{array}$ & ns & [25] \\
\hline & & Peripheral blood & $\begin{array}{l}\text { down } \\
\text { up }\end{array}$ & $\begin{array}{l}{[28]} \\
{[40]}\end{array}$ \\
\hline \multirow{6}{*}{ Stromelysins } & \multirow{3}{*}{ MMP3 } & Ectopic endometrium & up & {$[34,35,41,42]$} \\
\hline & & Eutopic endometrium & down & [34] \\
\hline & & Peripheral blood & ns & [29] \\
\hline & MMP10 & Ectopic endometrium & up & [35] \\
\hline & & Ectopic endometrium & up & {$[43,44]$} \\
\hline & MMP11 & Eutopic endometrium & down & {$[34]$} \\
\hline \multirow{3}{*}{ Matrilysins } & \multirow{2}{*}{ MMP7 } & Ectopic endometrium & up & {$[43,45,46]$} \\
\hline & & Peripheral blood & up & [45] \\
\hline & \multirow[t]{2}{*}{ MMP26 } & Ectopic endometrium & up & [27] \\
\hline \multirow{3}{*}{ Membrane-type MMPs } & & Ectopic endometrium & up & {$[33,37]$} \\
\hline & MT1-MMP & Eutopic endometrium & up & [36] \\
\hline & & Peritoneal fluid & down & [31] \\
\hline \multirow[b]{3}{*}{ Other MMPs } & MT5-MMP & Eutopic endometrium & up & [47] \\
\hline & MMP12 & Ectopic endometrium & up & [30] \\
\hline & MMP23 & Ectopic endometrium & up & [27] \\
\hline
\end{tabular}

MMP, matrix metalloproteinase; ns, no significant difference.

\subsection{Complexity of MMP Regulation in Endometriosis}

Over the past few years, evidence has shown that MMPs play an important role in the mechanisms involved in the occurrence and treatment of endometriosis. The epidermal growth factor receptor (EGFR)-MMP7 signaling pathway has been shown to be involved in the regulation of epithelial-mesenchymal transition (EMT) during the progression of endometriosis [45]. Moreover, chloride channel-3 (CIC3) and stress-induced 
phosphoprotein 1 enhance the activity of MMP9, while microRNA-33b has the opposite effect [48-50]. The fibrinogen alpha chain is upregulated and affects MMP2 in endometriosis [51]. Moreover, it has been shown that leptin promotes cell migration and invasion and that the cyclooxygenase-prostaglandin E2 (PGE2)-pAKT axis can promote angiogenesis via MMP2 [37,52]. In an in vivo trial, Shu et al. observed that the silencing of aquaporin 1, a water-channel protein, could influence the expression of invasion-related factors (MMP2, MMP9, TIMP1, and TIMP2), alleviating the progression of endometriosis in a mouse model [53]. Lipoxin A4 (LXA4) is a lipid medium that is widely involved in the establishment of endometriosis [54,55]. Moreover, LAX4 can suppress estrogen-mediated EMT via binding to its receptor and can inhibit the activities of MMP2 and MMP9 [56].

It is well known that the microenvironment of patients with endometriosis is inflammatory. Interleukin (IL)-2 and IL-27 synergistically inhibit MMP9 expression by maintaining the balance of interferon (IFN) $-\gamma$ and IL-10, thereby improving the invasive ability of endometriosis cells [57]. Lin et al. reported that IL-34, through activating signal transducer and activator of transcription 6 (STAT6), promoted the expression of MMP9 in endometriosis in vitro and in vivo via the colony-stimulating factor 1 receptor/Janus kinase 3/STAT6 pathway [58]. Moreover, IL-37 affects downstream MMP9 expression via a variety of signaling pathways and regulates the biological behavior of endometrial stromal cells [59]. MMP2 and MMP9 can be regarded as the most typical downstream biomarkers in the progression of endometriosis. Furthermore, as shown in Figure 1, various extracellular factors, such as estrogen [60], cytokines [57-59], iron overload [61], and environmental contaminants $[62,63]$, contribute to the regulation of MMPs expression.

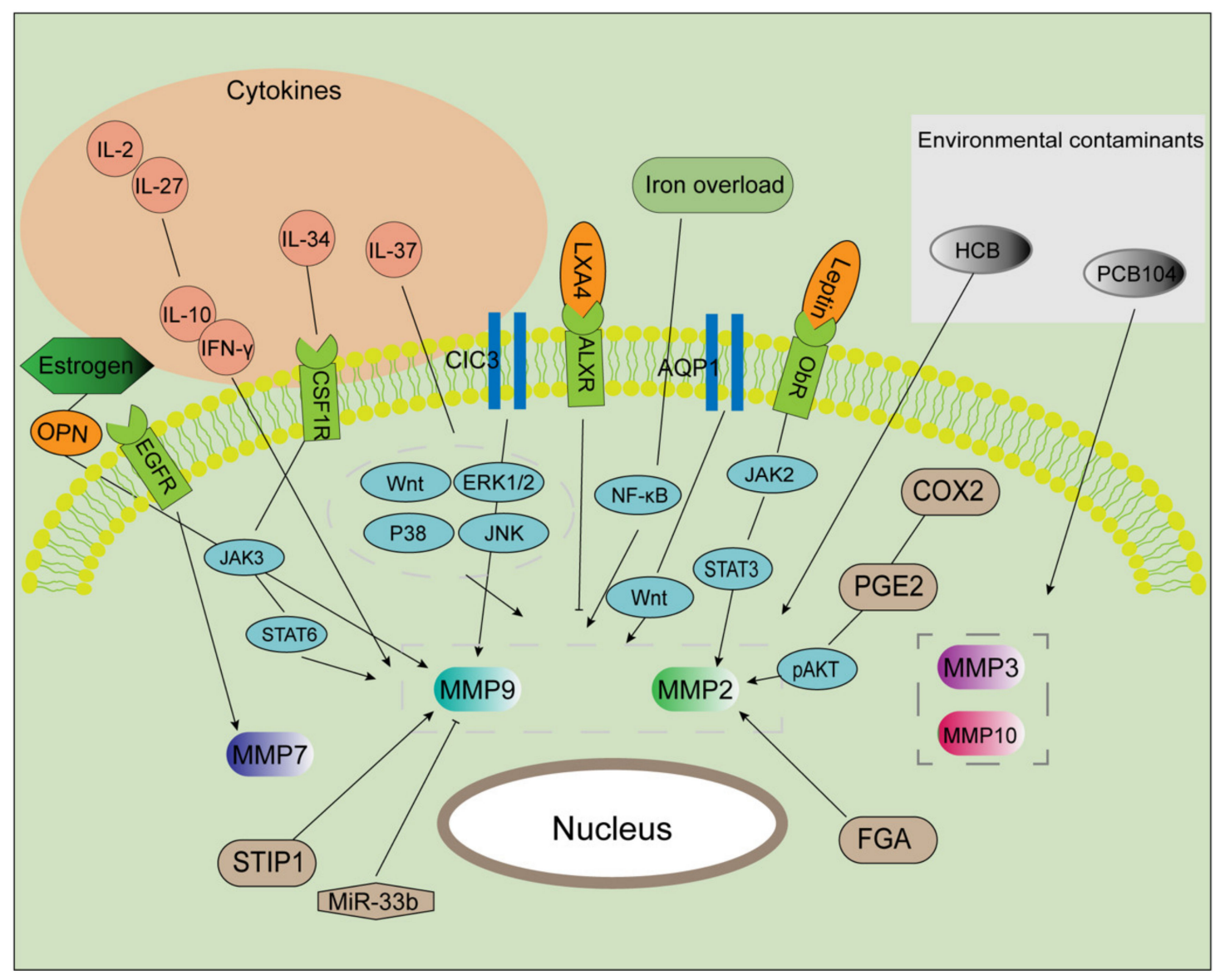

Figure 1. Multiple factors regulate MMP activities. After exposure to certain environmental contaminants (e.g., PCB104 and HCB), the expression of MMPs (MMP3, 10, 2, and 9) is markedly enhanced. IL-37 upregulates the expression of MMPs via multiple signaling pathways. IL-2 and IL-27 were found to maintain the balance of IL-10 and IFN- $\gamma$, promoting MMP2 and 
MMP9 expression and then inducing cell invasion and proliferation. IL-34 binds to CSF1R, which activated the JAK/STAT6 pathway in an autocrine manner. Estrogen induces MMP9 expression via the OPN. CIC3 and STIR1 improve the activity of MMP9, while miR-33b inhibits it. AQP1 promotes the expression of MMP2 and 9 via the Wnt signaling pathway. The COX2/PGE2/pAKT axis, as well as the leptin/JAK2/STAT3 axis, serves as a significant regulator in increasing MMP2 expression. Additionally, MMP2 is a target of FGA and LXA4. MMP7 is a downstream component in the EGFR-mediated signaling pathway. Iron markedly increases EMT and MMP2/9 activities in endometriosis.

MMP, matrix metalloproteinase; PCB104, polychlorinated biphenyl 104; HCB, hexachlorobenzene; CSF1R, colony-stimulating factor 1 receptor; OPN, osteopontin; CIC3, chloride channel-3; STIR1, stress-induced phosphoprotein 1; miR, microRNA; AQP1, aquaporin 1; FGA, fibrinogen alpha chain; COX2, cyclooxygenase 2; PGE2, prostaglandin E2; p, phosphorylated; JAK2, Janus kinase 2; STAT3, signal transducer and activator of transcription 3; LXA4, lipoxin A4; EMT, epithelial-mesenchymal transition.

\section{The Role of MMPs in the Pathophysiology of Endometriosis}

MMPs are influenced by changes in steroid hormone concentration levels and are involved in cyclic changes of the endometrium's structure and thickness [6]. The endometrium, whether it is eutopic endometrium or ectopic endometrium, is periodically shed in response to hormone fluctuations, but in endometriosis, it changes at the cellular level, e.g., in epithelial-mesenchymal transition (EMT), cell migration, and invasion, and at the tissue/organism level, e.g., in angiogenesis, fibrosis, and immunological aspects (Figure 2). There is no doubt that MMPs play a vital role in this process.

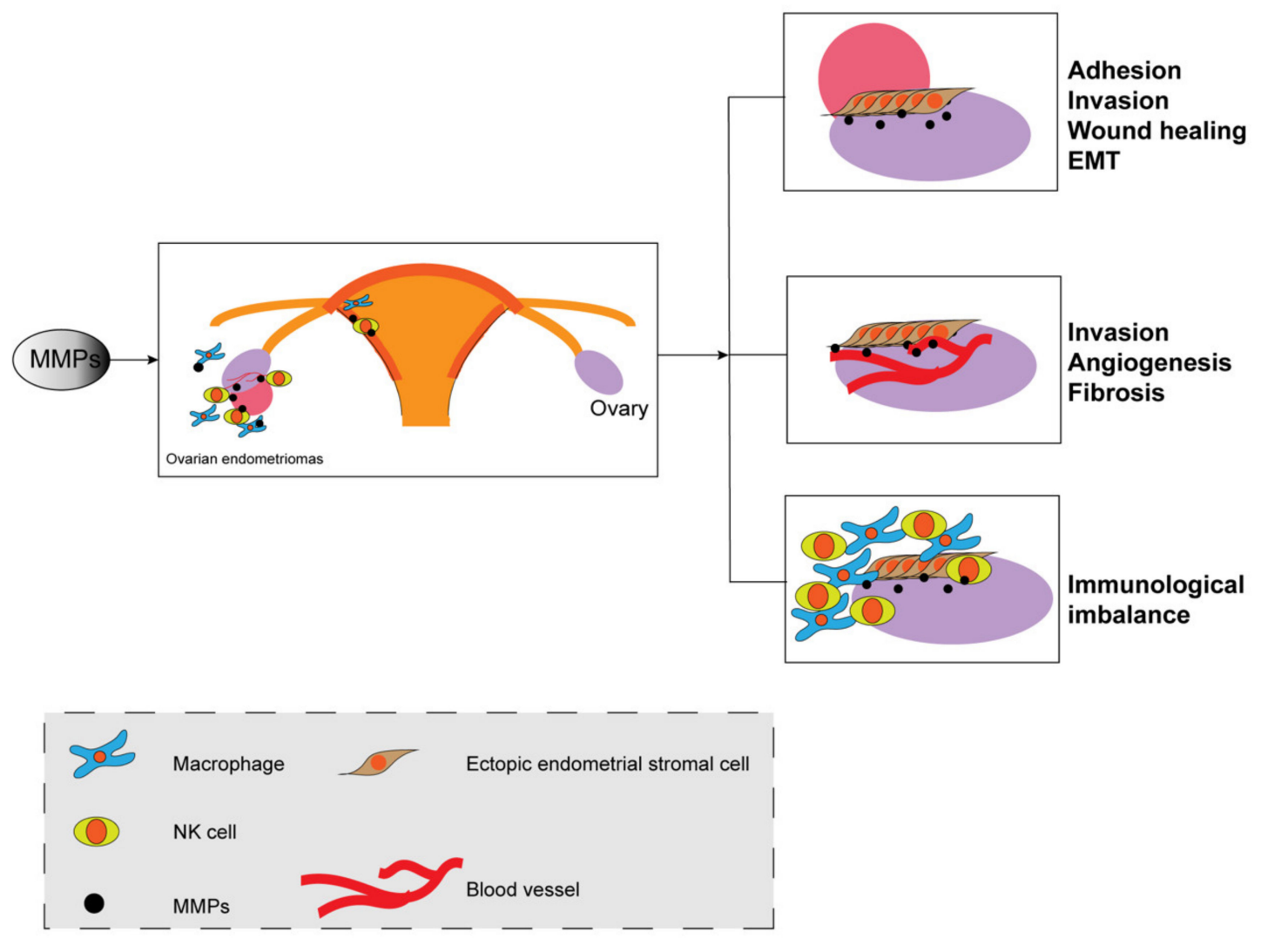

Figure 2. The role of MMPs in the pathophysiology of endometriosis.

In endometriosis, MMPs play a key role in various pathophysiological processes. The endometrium is shed during menstruation due to the fluctuation of hormones, and MMPs then accelerate the growth of the new endometrium to cover the wound. Free endometriotic cells pass through the fallopian tube; adhere to the surfaces of the peritoneum, ovary, and 
other organs; degrade the extracellular matrix; invade the new site; promote angiogenesis. Immunocytes, such as macrophages, kill the free cells upon coming into contact with them. MMPs are crucial for the aforementioned processes.

\subsection{MMPs at the Cellular Level}

\subsubsection{Migration and Invasion}

Endometriosis is a common benign gynecological disease characterized by a high migratory and invasive potential. In order to migrate, invade, and grow in new places, the cells establish cell-cell or cell-ECM interactions. In a study of the endometrial stromal cell line St-T1b and primary endometriotic stromal cells, researchers found that they participated in directional migration with significant collagen I remodeling, and this behavior was inhibited by the broad-spectrum MMP inhibitor N-isobutyl-N-(4-methoxyphenylsulfonyl) glycyl ydroxamic acid (NNGH) [64]. This confirms that MMPs are involved in ECM remodeling which is required for the establishment of ectopic endometriosis lesions. This initial step of lesion formation requires MMP activity for basement membrane and ECMprotein breakdown to support the subsequent invasion of endometriosis cells into the peritoneum $[6,65]$. The first membrane-type MMP to be named was MT1-MMP (also referred to as MMP14), which can directly degrade the ECM, especially collagen I, by locating invadopodia [66]. As downstream target molecules in the complex network that regulates endometriosis invasion, MMPs are altered by a diverse range of substances. For instance, the cytokines IL-2 and IL-27 promote the expression of MMPs, enhancing invasion by maintaining the homeostasis of IL-10 and IFN- $\gamma$ [57]. Moreover, exposure to bisphenol A (BPA) exposure increases cell invasion (through MMP2 and MMP9) in a dose-dependent manner, as shown by an in vitro study [67]. In addition to cytokines [57,58] and environmental contaminants [67,68], estrogen [56,69-71], oxidative stress [71,72], and autophagy [73,74] all impact invasion. An increasing number of researchers have explored inhibiting cell invasion or the metastasis of endometriosis by decreasing MMP expression. These findings have shown that MMPs are involved in the occurrence and progression of endometriosis by enhancing the invasion of ectopic endometrial cells.

\subsubsection{Epithelial-Mesenchymal Transition}

When cells lose their epithelial characteristics and acquire the features of mesenchymal cells, this is known as "epithelial-mesenchymal transition". This process includes a loss of polarity, impaired cell adhesion, and the acquisition of the ability to migrate. Several MMPs have been found to be involved in various cancers, such as gastric cancer, colorectal cancer, ovarian cancer, and prostate cancer [75-78]. When the expression of Par3 (a marker of cell polarity) and occludin (a tight-junction protein) decreases, the polarity of epithelial cells and the tight junctions between cells decrease $[79,80]$, and then, there is an increase in the migration and invasion abilities [81,82]. These features are beneficial for the formation and development of the new lesion through epithelial-mesenchymal transition. Chatterjee et al. reported that MMP7 promoted epithelial-mesenchymal transition in ovarian endometriosis, and EGF upregulated the expression of MMP7 through the ERK1-AP1 pathway [45]. MMP14 regulates the function and formation of invadopodia, which controls the migration and invasion abilities of mesenchymal cells [83]. Therefore, we speculate that MMPs may play a key role in regulating the EMT process in endometriosis. However, since there are few in-depth studies on the relationship between MMPs and epithelial-mesenchymal transition in endometriosis, this needs to be further explored.

\subsection{MMPs at the Tissue/Organism Level}

\subsubsection{Angiogenesis}

Angiogenesis is activated after the invasion. Moreover, the establishment and development of ectopic lesions require vasculogenesis for the lesions to be maintained. Angiogenesis is an invasive process initiated by MMPs [84] that contributes to endothelial cells detaching and migrating into new sites. In humans, at least 14 MMPs have been 
found in the vascular endothelium [12]. Specifically, MMP1, 8, and 13, which belong to the collagenases, are associated with angiogenesis. MMP1 promotes the expression of vascular endothelial growth factor (VEGF) receptor 2 (VEGFR2) [85], while MMP7 promotes angiogenesis by activating the VEGF pathway and degrading VEGFR1 [86]. Similarly, TIMP can regulate angiogenesis by inhibiting neovascularization [87]. Interestingly, MMPs are not only associated with angiogenesis but can also, in turn, be activated by angiogenic factors, such as VEGF and fibroblast growth factors (FGFs) [8].

One analogy is that the "ECM" is a reservoir filled with diverse factors, including VEGF, transforming growth factors, FGFs, and proteases [88,89]. The "ECM" here, unlike the aforementioned ECM that is rich in collagens and glycoproteins, but the so-called "non-ECM" contains growth factors and cell adhesion molecules. This explains why MMPs participate in angiogenesis. MMPs can release various factors by degrading non-ECM. This forms a vicious cycle that promotes the progression of endometriosis, and MMPs may be an indispensable factor among these processes.

\subsubsection{Fibrosis}

Vigano et al. challenged the obsolete definition of endometriosis and placed fibrosis or myofibroblasts in the public eye [90]. These authors suggested that altering the new definition could greatly reduce the misjudgment of endometriosis and redirect current treatments in a more effective direction. In terms of the real role of MMPs in fibrosis, a previous study revealed the effect of BPA on endometriosis, especially in collagen accumulation. The results demonstrated that exposure to BPA contributed to fibrosis by increasing the synthesis of collagen I and III and decreasing MMP2 and MMP14 expression [91]. Beyond that, another study reported that MT1-MMP deficiency caused the fibrosis of soft tissue because of a reduction in collagen degradation [92]. Interestingly, the findings of Matsuzaki et al. were the opposite. These authors observed that increased matrix stiffness promoted not only collagen I synthesis, but also MMP1 and MMP14 expression [93]. These results can be attributed to the fact that there may be a precise balance between collagen synthesis and degradation that should be explored in the future. Despite this, it is undeniable that MMPs play a vital role in the formation of collagen, which is important for the gradual fibrosis of endometriosis.

\subsubsection{Immunological Imbalance}

Endometriosis is a chronic inflammatory disorder. Several studies have analyzed numerous cytokines, chemokines, and immunocytes that are altered in endometriosis [94-96]. Oosterlynck et al. found that the activity of natural killer (NK) cells was decreased in females with endometriosis [97]. Notably, microenvironment-associated ECM components regulate NK cells' functions. MMPs can help tumor cells evade immune surveillance via the cleavage of NK group 2 member D (NKG2D) ligands from cell surfaces [98,99]. Additionally, they can cause the shedding of intercellular-adhesion molecule 1, a protein that participates in the process of NK cells' recognition of their target cells [95,100]. Macrophages, acting as another scavenger in endometriosis, are also impaired. The reduced expression of MMPs on macrophages may be associated with their impaired phagocytic activity, as MMPs can help the macrophages to degrade the ECM of target cells that will be phagocyted [101]. Wu et al. suggested that the levels and activities of MMP9 in peritoneal macrophages were decreased and regulated by prostaglandin (PG) E2 via the EP2/EP4 pathway. Collectively, this may be a potent mechanism of the decrease in the phagocytotic capability of macrophages [102]. The cytokines detected in the peritoneal fluid show different expressions and may be involved in regulating MMPs. IL-10 and IFN have the ability to increase the expression of MMP2 and MMP9 [57], while IL-6 can upregulate the expression of MMP9 [103], and IL- $\beta$ can positively adjust MMP13 activity [104]. Overall, it has been suggested that MMPs may cause an imbalance in local microenvironmental immunity in endometriosis and induce the occurrence of disease, by modulating immune cells or autoimmune factors. 
As previously mentioned, endometriosis is a complex disease that is regulated by numerous interacting factors which interact. Similarly, the involvement of MMPs is not limited to the aforementioned stages in the progression of endometriosis, and their additional functions require further investigation.

\section{Potential Value of Inhibiting MMPs in Endometriosis}

\subsection{MMPs as Biomarkers in Endometriosis}

One study has suggested that MMP3 may be one of the most significant genes of the 291 genes that are responsible for endometriosis [105]. Collectively, MMPs are important in the progress of endometriosis. A cross-sectional study found higher MMP2 expression in the sera of women with stage III/IV endometriosis than in women with stage I/II endometriosis, although there were no differences between women with and without endometriosis [106], which may be due to the low sample size $(n=30)$. Another study showed that MMP2 and TIMP2 were associated with advanced-stage endometriosis [107]. In addition, $\mathrm{Wu}$ and other experts found that the expression of MMP9 was increased in patients with recurrent ovarian endometriosis [108]. The expression of MMPs could have a certain reference value for judging the stage of the disease. However, there have been few clinical studies in this area; larger sample sizes and more rigorous experimental protocols are required to verify this.

\subsection{MMPs as Therapeutic Targets}

The current medical therapies may be classified into two groups: surgery and conservative medication. Surgery is effective but can be traumatic. Gonadotropin-releasing hormone $(\mathrm{GnRH})$ agonists and synthetic progestins are commonly used in clinics; however, they can cause numerous systemic side effects due to the over-suppression of endogenous steroid hormone levels [109]. Most patients show severe menopausal symptoms, such as hot flashes, night sweats, sexual hypoactivity, and osteoporosis [110]. Thus, there are still challenges in the treatment of endometriosis, and it is urgent to investigate additional optimal therapies.

MMPs are required for endometrial cells to detach from the endometrium and invade the peritoneum surface, for vascular endothelial cells to migrate to the new vessel, for macrophages to recognize and phagocytose escaped cells, and for NK cells to kill targeted cells, suggesting that MMPs may be an important target for treating endometriosis. To date, several types of MMP inhibitors have been applied to treat malignant tumors. As mentioned previously, TIMPs are natural inhibitors of MMPs. Arkadash et al. modified a high-affinity and highly specific inhibitor of MMP14, which is a TIMP analog [111]. Additionally, numerous monoclonal antibodies against MMP9 or MMP14 have been evaluated in clinical trials for gastric and gastroesophageal junction adenocarcinoma, ulcerative colitis, and breast tumors [112-114]. However, various side effects have followed. Marimastat (BB-2516) showed much promise in a preclinical setting and reached phases II and III for numerous tumors. However, many patients could not ignore the "musculoskeletal syndrome", such as stiffness, inflammation, and joint pain, which forced them to eventually discontinue their participation in the study [115]. The anti-metastatic activity of Neovastat (AE-941) depends on its inhibitory effect on MMPs' enzymatic activity [116]. However, patients could not tolerate its adverse effects, including flatulence, diarrhea, nausea, constipation, and rashes [117]. Although their final results may be unsatisfactory due to the intolerable side effects, their value is evident. The development of inhibitors that are specific for certain MMPs but do not cross-react with other MMPs is critical for the development of future MMP inhibitors.

Surprisingly, few studies have focused on the application of anti-MMP compounds for patients with endometriosis. In endometriosis, the levels of TIMPs are controversial, but this has not prevented studies from demonstrating that promoting their expression can suppress endometrial cell invasion. Most studies regard MMPs as biomarkers and have proven that medicine has the ability to repress the expression of MMPs. However, the 
specific mechanism by which MMPs function is yet to be elucidated. Sharpe et al. injected 40 female Sprague-Dawley rats with GnRH-a and a diluent. After examining the peritoneal fluid, their results suggested that GnRH-a altered the activity of MMPs [118]. Moreover, it has been reported that dehydrocostus lactone, isolated from Aucklandia lappa, inhibited the expression of MMP2 and MMP9 in endometriosis-associated macrophages (EAMs) and influenced the polarization of macrophages [119]. Resveratrol exerts its anti-inflammatory effect by modulating MMP activity [26]. Furthermore, cisplatin combined with letrozole was found to inhibit angiogenesis in a rat model of endometriosis by altering MMP2 activity [120]. As depicted in Figure 1 and Table 2, MMPs have been reported to play a key role in the invasion. However, additional in-depth mechanistic studies should be conducted; in particular, it is necessary to conduct a safety assessment for anti-MMP interventions. Overall, examining numerous medicines has provided evidence to support their anti-endometriosis activity by reducing MMP activity. However, there is no relevant research on MMP antibodies in endometriosis. Studies on this should be conducted in the future.

Table 2. MMP interventions for endometriosis.

\begin{tabular}{|c|c|c|c|c|c|}
\hline Drug(s) & In Vivo or In Vitro & Species or Cell Type & MMP & Function & Reference \\
\hline GnRH-a & In vivo & Rats & MMPs & Inhibit invasion & [118] \\
\hline $\begin{array}{l}\text { Atorvastatin and } \\
\text { amygdalin }\end{array}$ & In vivo & Rats & MMP2, MMP9 & Inhibit invasion & [121] \\
\hline Jiawei Foshou San & In vivo & Rats & MMP2, MMP9 & Inhibit invasion & [122] \\
\hline Naringeni & In vivo & Rats & MMP2, MMP9 & Inhibit invasion & [123] \\
\hline Nobiletin & In vivo & Mice & MMP1, MMP3 & Inhibit invasion & [124] \\
\hline $\begin{array}{c}\text { Euterpe oleracea } \\
\text { extract }\end{array}$ & In vivo & Rats & MMP9 & Inhibit invasion & [125] \\
\hline Doxycycline & In vitro & $\begin{array}{c}12 Z \text { epithelial } \\
\text { endometriotic cells, } \\
\text { human endometriotic } \\
\text { stromal cells }\end{array}$ & MMP2, MMP9 & Inhibit invasion & [126] \\
\hline $\begin{array}{c}\text { Pueraria flower } \\
\text { extract }\end{array}$ & $\begin{array}{l}\text { In vitro and } \\
\text { in vivo }\end{array}$ & $\begin{array}{l}\text { Human endometriotic } \\
\text { cells and mice }\end{array}$ & MMP2, MMP9 & Inhibit invasion & [127] \\
\hline Cervus elaphus & In vitro & $\begin{array}{c}\text { Human endometriotic } \\
\text { cells }\end{array}$ & MMP2, MMP9 & Inhibit invasion & [128] \\
\hline $\begin{array}{l}\text { Cisplatin and } \\
\text { letrozole }\end{array}$ & In vivo & Rats & MMP2 & $\begin{array}{l}\text { Inhibit } \\
\text { angiogenesis }\end{array}$ & [120] \\
\hline $\begin{array}{l}\text { Dehydrocostus } \\
\text { Lactone }\end{array}$ & In vitro & Human macrophages & MMP2, MMP9 & Inhibit activation & [119] \\
\hline Resveratrol & In vivo & $\begin{array}{l}\text { Human (endometrial } \\
\text { tissue, fluid, and } \\
\text { serum) }\end{array}$ & MMP2, MMP9 & Anti-inflammatory & [26] \\
\hline Montelukast & In vivo & Rats & MMP2 & $\begin{array}{c}\text { Decrease the area } \\
\text { of lesions }\end{array}$ & [129] \\
\hline Curcumin & In vivo & Mice & $\begin{array}{l}\text { MMP2,TIMP2, } \\
\text { MT1-MMP }\end{array}$ & $\begin{array}{l}\text { Decrease the area } \\
\text { of lesions }\end{array}$ & [130] \\
\hline $\begin{array}{l}\text { 1,25-Dihydroxy } \\
\text { Vitamin D3 }\end{array}$ & In vitro & $\begin{array}{l}\text { Human endometriotic } \\
\text { stromal cells }\end{array}$ & MMP2, MMP9 & $\begin{array}{l}\text { May inhibit } \\
\text { invasion }\end{array}$ & [131] \\
\hline
\end{tabular}

MMP, matrix metalloproteinase.

\section{Summary and Perspective}

At present, endometriosis is a challenge for patients, clinicians, and researchers on account of the poor understanding of how and why the disease develops. As a result, the effects of clinical medication remain unsatisfactory. MMPs have been an intriguing target for decades. However, no MMP antibodies or inhibitors have yet been used in clinical settings due to their intolerable side effects or non-specificity. Hence, further investigation of their mechanisms and inhibitors is required; this will enhance the therapeutic abilities of drugs. In endometriosis, information relevant to anti-MMP treatment is lacking, which poses significant challenges. Considering the crucial role of MMPs in the development of 
endometriosis, it is easy to see the necessity of exploiting anti-MMP drugs. Endometriosis is a benign disease that behaves in a malignant manner, and it is important to weigh the advantages and disadvantages of its treatment. Therefore, many aspects of using MMPs as a therapeutic target need to be carefully considered: For example, can anti-MMP approaches be used in endometriosis? How can anti-MMP treatments achieve potent effects without impairing gestation? Furthermore, how can inhibitors or antibodies be optimally designed in order to reduce side effects? This review highlights the location, function, and potential value of MMPs, which will help to improve the understanding of the categories and functions of these key enzymes. Moreover, the review aims to promote the optimization of future therapies (i.e., making them more specific and patient-friendly).

Author Contributions: J.K. performed the literature search and prepared the figures, tables, and manuscript. J.Y. helped to edit the manuscript. Z.Z. designed and supervised the manuscript. M.L. reviewed and modified the manuscript. All authors have read and agreed to the published version of the manuscript.

Funding: This research was supported by the Science and Technology Commission of Shanghai Municipality, China [grant number. 17401930200 to Zhiling Zhu]; the Major Research Program of the National Natural Science Foundation of China [NSFC, grant numbers. 31970798, 92057119]; the Innovation-Oriented Science and Technology Grant from the NPFPC Key Laboratory of Reproduction Regulation [grant number. CX2017-2]; the Program for Zhuoxue of Fudan University [grant number. JIF157602]; and the Support Project for Original Personalized Research of Fudan University to Mingqing Li.

Institutional Review Board Statement: Not applicable.

Informed Consent Statement: Not applicable.

Data Availability Statement: Not applicable.

Conflicts of Interest: The authors declare no conflict of interest.

\section{References}

1. Samimi, M.; Pourhanifeh, M.H.; Mehdizadehkashi, A.; Eftekhar, T.; Asemi, Z. The role of inflammation, oxidative stress, angiogenesis, and apoptosis in the pathophysiology of endometriosis: Basic science and new insights based on gene expression. $J$. Cell. Physiol. 2019, 234, 19384-19392. [CrossRef] [PubMed]

2. Farland, L.V.; Prescott, J.; Sasamoto, N.; Tobias, D.K.; Gaskins, A.J.; Stuart, J.J.; Carusi, D.A.; Chavarro, J.E.; Horne, A.W.; RichEdwards, J.W.; et al. Endometriosis and Risk of Adverse Pregnancy Outcomes. Obstet. Gynecol. 2019, 134, 527-536. [CrossRef] [PubMed]

3. Zondervan, K.T.; Becker, C.M.; Koga, K.; Missmer, S.A.; Taylor, R.N.; Vigano, P. Endometriosis. Nat. Rev. Dis. Primers 2018, 4, 9. [CrossRef]

4. Tsang, K.Y.; Cheung, M.C.; Chan, D.; Cheah, K.S. The developmental roles of the extracellular matrix: Beyond structure to regulation. Cell Tissue Res. 2010, 339, 93-110. [CrossRef]

5. Gross, J.; Lapiere, C.M. Collagenolytic activity in amphibian tissues: A tissue culture assay. Proc. Natl. Acad. Sci. USA 1962, 48 , 1014-1022. [CrossRef] [PubMed]

6. Pitsos, M.; Kanakas, N. The role of matrix metalloproteinases in the pathogenesis of endometriosis. Reprod. Sci. 2009, 16, 717-726. [CrossRef]

7. Kapoor, C.; Vaidya, S.; Wadhwan, V.; Kaur, G.; Pathak, A. Seesaw of matrix metalloproteinases (MMPs). J. Cancer Res. Ther. 2016, 12, 28-35. [CrossRef] [PubMed]

8. Quintero-Fabian, S.; Arreola, R.; Becerril-Villanueva, E.; Torres-Romero, J.C.; Arana-Argaez, V.; Lara-Riegos, J.; Ramirez-Camacho, M.A.; Alvarez-Sanchez, M.E. Role of Matrix Metalloproteinases in Angiogenesis and Cancer. Front. Oncol. 2019, 9, 1370. [CrossRef]

9. Balkowiec, M.; Maksym, R.B.; Wlodarski, P.K. The bimodal role of matrix metalloproteinases and their inhibitors in etiology and pathogenesis of endometriosis (Review). Mol. Med. Rep. 2018, 18, 3123-3136. [CrossRef] [PubMed]

10. Garcia-Fernandez, N.; Jacobs-Cacha, C.; Mora-Gutierrez, J.M.; Vergara, A.; Orbe, J.; Soler, M.J. Matrix Metalloproteinases in Diabetic Kidney Disease. J. Clin. Med. 2020, 9, 472. [CrossRef]

11. Stawowczyk, M.; Wellenstein, M.D.; Lee, S.B.; Yomtoubian, S.; Durrans, A.; Choi, H.; Narula, N.; Altorki, N.K.; Gao, D.; Mittal, V. Matrix Metalloproteinase 14 promotes lung cancer by cleavage of Heparin-Binding EGF-like Growth Factor. Neoplasia 2017, 19, 55-64. [CrossRef] [PubMed] 
12. Wang, X.; Khalil, R.A. Matrix Metalloproteinases, Vascular Remodeling, and Vascular Disease. Adv. Pharmacol. 2018, 81, 241-330. [CrossRef] [PubMed]

13. Fischer, T.; Riedl, R. Inhibitory Antibodies Designed for Matrix Metalloproteinase Modulation. Molecules 2019, 24, 2265. [CrossRef] [PubMed]

14. Agren, M.S.; Mirastschijski, U.; Karlsmark, T.; Saarialho-Kere, U.K. Topical synthetic inhibitor of matrix metalloproteinases delays epidermal regeneration of human wounds. Exp. Dermatol. 2001, 10, 337-348. [CrossRef] [PubMed]

15. Hao, J.L.; Nagano, T.; Nakamura, M.; Kumagai, N.; Mishima, H.; Nishida, T. Effect of galardin on collagen degradation by Pseudomonas aeruginosa. Exp. Eye Res. 1999, 69, 595-601. [CrossRef]

16. Gatto, C.; Rieppi, M.; Borsotti, P.; Innocenti, S.; Ceruti, R.; Drudis, T.; Scanziani, E.; Casazza, A.M.; Taraboletti, G.; Giavazzi, R. BAY 12-9566, a novel inhibitor of matrix metalloproteinases with antiangiogenic activity. Clin. Cancer Res. Off. J. Am. Assoc. Cancer Res. 1999, 5, 3603-3607.

17. Lockhart, A.C.; Braun, R.D.; Yu, D.; Ross, J.R.; Dewhirst, M.W.; Humphrey, J.S.; Thompson, S.; Williams, K.M.; Klitzman, B.; Yuan, F.; et al. Reduction of wound angiogenesis in patients treated with BMS-275291, a broad spectrum matrix metalloproteinase inhibitor. Clin. Cancer Res. Off. J. Am. Assoc. Cancer Res. 2003, 9, 586-593.

18. Egeblad, M.; Werb, Z. New functions for the matrix metalloproteinases in cancer progression. Nat. Rev. Cancer 2002, 2, 161-174. [CrossRef] [PubMed]

19. Zakiyanov, O.; Kalousova, M.; Zima, T.; Tesar, V. Matrix Metalloproteinases in Renal Diseases: A Critical Appraisal. Kidney Blood Press. Res. 2019, 44, 298-330. [CrossRef] [PubMed]

20. Rai, G.P.; Baird, S.K. Tissue inhibitor of matrix metalloproteinase-3 has both anti-metastatic and anti-tumourigenic properties. Clin. Exp. Metastasis 2020, 37, 69-76. [CrossRef]

21. Fujii, T.; Duarte, S.; Lee, E.; Ke, B.; Busuttil, R.W.; Coito, A.J. Tissue Inhibitor of Metalloproteinase 3 Deficiency Disrupts the Hepatocyte E-Cadherin/beta-Catenin Complex and Induces Cell Death in Liver Ischemia/Reperfusion Injury. Liver Transplant. 2020, 26, 113-126. [CrossRef]

22. Opdenakker, G.; Abu El-Asrar, A. Metalloproteinases mediate diabetes-induced retinal neuropathy and vasculopathy. Cell. Mol. Life Sci. 2019, 76, 3157-3166. [CrossRef]

23. Rodgers, W.H.; Osteen, K.G.; Matrisian, L.M.; Navre, M.; Giudice, L.C.; Gorstein, F. Expression and localization of matrilysin, a matrix metalloproteinase, in human endometrium during the reproductive cycle. Am. J. Obstet. Gynecol. 1993, 168, $253-260$. [CrossRef]

24. Sui, X.; Li, Y.; Sun, Y.; Li, C.; Li, X.; Zhang, G. Expression and significance of autophagy genes LC3, Beclin1 and MMP-2 in endometriosis. Exp. Ther. Med. 2018, 16, 1958-1962. [CrossRef] [PubMed]

25. Szymanowski, K.; Mikolajczyk, M.; Wirstlein, P.; Dera-Szymanowska, A. Matrix metalloproteinase-2 (MMP-2), MMP-9, tissue inhibitor of matrix metalloproteinases (TIMP-1) and transforming growth factor-beta2 (TGF-beta2) expression in eutopic endometrium of women with peritoneal endometriosis. Ann. Agric. Environ. Med. 2016, 23, 649-653. [CrossRef] [PubMed]

26. Kodarahmian, M.; Amidi, F.; Moini, A.; Kashani, L.; Shabani Nashtaei, M.; Pazhohan, A.; Bahramrezai, M.; Berenjian, S.; Sobhani, A. The modulating effects of Resveratrol on the expression of MMP-2 and MMP-9 in endometriosis women: A randomized exploratory trial. Off. J. Int. Soc. Gynecol. Endocrinol. 2019, 35, 719-726. [CrossRef]

27. Borghese, B.; Mondon, F.; Noël, J.C.; Fayt, I.; Mignot, T.M.; Vaiman, D.; Chapron, C. Gene expression profile for ectopic versus eutopic endometrium provides new insights into endometriosis oncogenic potential. Mol. Endocrinol. 2008, 22, $2557-2562$. [CrossRef] [PubMed]

28. Pino, M.; Galleguillos, C.; Torres, M.; Sovino, H.; Fuentes, A.; Boric, M.A.; Johnson, M.C. Association between MMP1 and MMP9 activities and ICAM1 cleavage induced by tumor necrosis factor in stromal cell cultures from eutopic endometria of women with endometriosis. Reproduction 2009, 138, 837-847. [CrossRef]

29. Shan, K.; Ying, W.; Jian-Hui, Z.; Wei, G.; Na, W.; Yan, L. The function of the SNP in the MMP1 and MMP3 promoter in susceptibility to endometriosis in China. Mol. Hum. Reprod. 2005, 11, 423-427. [CrossRef]

30. Borghese, B.; Chiche, J.D.; Vernerey, D.; Chenot, C.; Mir, O.; Bijaoui, G.; Bonaiti-Pellie, C.; Chapron, C. Genetic polymorphisms of matrix metalloproteinase 12 and 13 genes are implicated in endometriosis progression. Hum. Reprod. 2008, 23, 1207-1213. [CrossRef] [PubMed]

31. Laudanski, P.; Szamatowicz, J.; Ramel, P. Matrix metalloproteinase-13 and membrane type-1 matrix metalloproteinase in peritoneal fluid of women with endometriosis. Gynecol. Endocrinol. 2005, 21, 106-110. [CrossRef]

32. Weigel, M.T.; Kramer, J.; Schem, C.; Wenners, A.; Alkatout, I.; Jonat, W.; Maass, N.; Mundhenke, C. Differential expression of MMP-2, MMP-9 and PCNA in endometriosis and endometrial carcinoma. Eur. J. Obstet. Gynecol. Reprod. Biol. 2012, $160,74-78$. [CrossRef]

33. Ueda, M.; Yamashita, Y.; Takehara, M.; Terai, Y.; Kumagai, K.; Ueki, K.; Kanda, K.; Hung, Y.C.; Ueki, M. Gene expression of adhesion molecules and matrix metalloproteinases in endometriosis. Off. J. Int. Soc. Gynecol. Endocrinol. 2002, 16, 391-402. [CrossRef]

34. Uzan, C.; Cortez, A.; Dufournet, C.; Fauvet, R.; Siffroi, J.P.; Daraï, E. Eutopic endometrium and peritoneal, ovarian and bowel endometriotic tissues express a different profile of matrix metalloproteinases-2, -3 and -11 , and of tissue inhibitor metalloproteinases-1 and -2. Virchows Arch. 2004, 445, 603-609. [CrossRef] [PubMed] 
35. Luddi, A.; Marrocco, C.; Governini, L.; Semplici, B.; Pavone, V.; Luisi, S.; Petraglia, F.; Piomboni, P. Expression of Matrix Metalloproteinases and Their Inhibitors in Endometrium: High Levels in Endometriotic Lesions. Int. J. Mol. Sci. 2020, $21,2840$. [CrossRef] [PubMed]

36. Chung, H.W.; Lee, J.Y.; Moon, H.S.; Hur, S.E.; Park, M.H.; Wen, Y.; Polan, M.L. Matrix metalloproteinase-2, membranous type 1 matrix metalloproteinase, and tissue inhibitor of metalloproteinase-2 expression in ectopic and eutopic endometrium. Fertil. Steril. 2002, 78, 787-795. [CrossRef]

37. Jana, S.; Chatterjee, K.; Ray, A.K.; DasMahapatra, P.; Swarnakar, S. Regulation of Matrix Metalloproteinase-2 Activity by COX-2-PGE2-pAKT Axis Promotes Angiogenesis in Endometriosis. PLoS ONE 2016, 11, e0163540. [CrossRef]

38. Huang, H.F.; Hong, L.H.; Tan, Y.; Sheng, J.Z. Matrix metalloproteinase 2 is associated with changes in steroid hormones in the sera and peritoneal fluid of patients with endometriosis. Fertil. Steril. 2004, 81, 1235-1239. [CrossRef]

39. Paul, S.; Sharma, A.V.; Mahapatra, P.D.; Bhattacharya, P.; Reiter, R.J.; Swarnakar, S. Role of melatonin in regulating matrix metalloproteinase-9 via tissue inhibitors of metalloproteinase-1 during protection against endometriosis. J. Pineal Res. 2008, 44, 439-449. [CrossRef] [PubMed]

40. Bostanci Durmus, A.; Dincer Cengiz, S.; Yilmaz, H.; Candar, T.; Gursoy, A.Y.; Sinem Caglar, G. The levels of matrix metalloproteinase-9 and neutrophil gelatinase-associated lipocalin in different stages of endometriosis. J. Inst. Obstet. Gynaecol. 2019, 39, 991-995. [CrossRef] [PubMed]

41. Jana, S.; Paul, S.; Swarnakar, S. Curcumin as anti-endometriotic agent: Implication of MMP-3 and intrinsic apoptotic pathway. Biochem. Pharmacol. 2012, 83, 797-804. [CrossRef] [PubMed]

42. Lv, X.; Chen, P.; Liu, W. Down regulation of MiR-93 contributes to endometriosis through targeting MMP3 and VEGFA. Am. J. Cancer Res. 2015, 5, 1706-1717. [PubMed]

43. Vallvé-Juanico, J.; López-Gil, C.; Ponomarenko, J.; Melnychuk, T.; Castellví, J.; Ballesteros, A.; Colás, E.; Gil-Moreno, A.; Santamaria Costa, X. External validation of putative biomarkers in eutopic endometrium of women with endometriosis using NanoString technology. J. Assist. Reprod. Genet. 2020, 37, 2981-2987. [CrossRef] [PubMed]

44. Feng, X.; Qi, L.; Xu, X.; Feng, Y.; Gong, X.; Aili, A.; Chen, Y.; Xue, Z.; Xue, J.; Tong, X. Analysis of differences in the transcriptomic profiles of eutopic and ectopic endometriums in women with ovarian endometriosis. PeerJ 2021, 9, e11045. [CrossRef] [PubMed]

45. Chatterjee, K.; Jana, S.; DasMahapatra, P.; Swarnakar, S. EGFR-mediated matrix metalloproteinase-7 up-regulation promotes epithelial-mesenchymal transition via ERK1-AP1 axis during ovarian endometriosis progression. FASEB J. 2018, 32, 4560-4572. [CrossRef] [PubMed]

46. Itoh, H.; Mogami, H.; Bou Nemer, L.; Word, L.; Rogers, D.; Miller, R.; Word, R.A. Endometrial stromal cell attachment and matrix homeostasis in abdominal wall endometriomas. Hum. Reprod. 2018, 33, 280-291. [CrossRef]

47. Gaetje, R.; Holtrich, U.; Engels, K.; Kourtis, K.; Cikrit, E.; Kissler, S.; Rody, A.; Karn, T.; Kaufmann, M. Expression of membranetype 5 matrix metalloproteinase in human endometrium and endometriosis. Gynecol. Endocrinol. 2007, 23, 567-573. [CrossRef] [PubMed]

48. Guan, Y.T.; Huang, Y.Q.; Wu, J.B.; Deng, Z.Q.; Wang, Y.; Lai, Z.Y.; Wang, H.B.; Sun, X.X.; Zhu, Y.L.; Du, M.M.; et al. Overexpression of chloride channel-3 is associated with the increased migration and invasion ability of ectopic endometrial cells from patients with endometriosis. Hum. Reprod. 2016, 31, 986-998. [CrossRef]

49. Wang, H.S.; Tsai, C.L.; Chang, P.Y.; Chao, A.; Wu, R.C.; Chen, S.H.; Wang, C.J.; Yen, C.F.; Lee, Y.S.; Wang, T.H. Positive associations between upregulated levels of stress-induced phosphoprotein 1 and matrix metalloproteinase-9 in endometriosis/adenomyosis. PLoS ONE 2018, 13, e0190573. [CrossRef] [PubMed]

50. Yang, W.W.; Hong, L.; Xu, X.X.; Wang, Q.; Huang, J.L.; Jiang, L. Regulation of miR-33b on endometriosis and expression of related factors. Eur. Rev. Med. Pharmacol. Sci. 2017, 21, 2027-2033. [PubMed]

51. Chen, Y.; Li, H.; Cheng, H.Y.; Rui-Qiong, M.; Ye, X.; Cui, H.; Hong-Lan, Z.; Chang, X.H. Fibrinogen alpha chain is up-regulated and affects the pathogenesis of endometriosis. Reprod. Biomed. Online 2019, 39, 893-904. [CrossRef]

52. Ahn, J.H.; Choi, Y.S.; Choi, J.H. Leptin promotes human endometriotic cell migration and invasion by up-regulating MMP-2 through the JAK2/STAT3 signaling pathway. Mol. Hum. Reprod. 2015, 21, 792-802. [CrossRef]

53. Shu, C.; Shu, Y.; Gao, Y.; Chi, H.; Han, J. Inhibitory effect of AQP1 silencing on adhesion and angiogenesis in ectopic endometrial cells of mice with endometriosis through activating the Wnt signaling pathway. Cell Cycle 2019, 18, 2026-2039. [CrossRef] [PubMed]

54. Chen, S.; Wu, R.F.; Su, L.; Zhou, W.D.; Zhu, M.B.; Chen, Q.H. Lipoxin A4 regulates expression of the estrogen receptor and inhibits 17beta-estradiol induced p38 mitogen-activated protein kinase phosphorylation in human endometriotic stromal cells. Fertil. Steril. 2014, 102, 264-271. [CrossRef]

55. Wu, R.; Zhou, W.; Chen, S.; Shi, Y.; Su, L.; Zhu, M.; Chen, Q.; Chen, Q. Lipoxin A4 suppresses the development of endometriosis in an ALX receptor-dependent manner via the p38 MAPK pathway. Br. J. Pharmacol. 2014, 171, 4927-4940. [CrossRef]

56. Wu, R.F.; Huang, Z.X.; Ran, J.; Dai, S.J.; Lin, D.C.; Ng, T.W.; Chen, Q.X.; Chen, Q.H. Lipoxin A4 Suppresses Estrogen-Induced Epithelial-Mesenchymal Transition via ALXR-Dependent Manner in Endometriosis. Reprod. Sci. 2018, 25, 566-578. [CrossRef] [PubMed]

57. Qiu, X.M.; Lai, Z.Z.; Ha, S.Y.; Yang, H.L.; Liu, L.B.; Wang, Y.; Shi, J.W.; Ruan, L.Y.; Ye, J.F.; Wu, J.N.; et al. IL-2 and IL-27 synergistically promote growth and invasion of endometriotic stromal cells by maintaining the balance of IFN- $\gamma$ and IL-10 in endometriosis. Reproduction 2020, 159, 251-260. [CrossRef] 
58. Lin, K.; Ma, J.; Peng, Y.; Sun, M.; Xu, K.; Wu, R.; Lin, J. Autocrine Production of Interleukin-34 Promotes the Development of Endometriosis through CSF1R/JAK3/STAT6 signaling. Sci. Rep. 2019, 9, 16781. [CrossRef] [PubMed]

59. Jiang, J.; Yu, K.; Jiang, Z.; Xue, M. IL-37 affects the occurrence and development of endometriosis by regulating the biological behavior of endometrial stromal cells through multiple signaling pathways. Biol. Chem. 2018, 399, 1325-1337. [CrossRef]

60. Yang, M.; Jiang, C.; Chen, H.; Nian, Y.; Bai, Z.; Ha, C. The involvement of osteopontin and matrix metalloproteinase- 9 in the migration of endometrial epithelial cells in patients with endometriosis. Reprod. Biol. Endocrinol. 2015, 13, 95. [CrossRef] [PubMed]

61. Woo, J.H.; Choi, Y.S.; Choi, J.H. Iron-Storage Protein Ferritin Is Upregulated in Endometriosis and Iron Overload Contributes to a Migratory Phenotype. Biomedicines 2020, 8, 454. [CrossRef]

62. Chiappini, F.; Sanchez, M.; Miret, N.; Cocca, C.; Zotta, E.; Ceballos, L.; Pontillo, C.; Bilotas, M.; Randi, A. Exposure to environmental concentrations of hexachlorobenzene induces alterations associated with endometriosis progression in a rat model. Food Chem. Toxicol. 2019, 123, 151-161. [CrossRef]

63. Hu, T.; Yao, M.; Fu, X.; Chen, C.; Wu, R. Polychlorinated biphenyl 104 promotes migration of endometrial stromal cells in endometriosis. Toxicol. Lett. 2018, 290, 19-28. [CrossRef]

64. Stejskalová, A.; Fincke, V.; Nowak, M.; Schmidt, Y.; Borrmann, K.; von Wahlde, M.K.; Schäfer, S.D.; Kiesel, L.; Greve, B.; Götte, M. Collagen I triggers directional migration, invasion and matrix remodeling of stroma cells in a 3D spheroid model of endometriosis. Sci. Rep. 2021, 11, 4115. [CrossRef] [PubMed]

65. Rydlova, M.; Holubec, L., Jr.; Ludvikova, M., Jr.; Kalfert, D.; Franekova, J.; Povysil, C.; Ludvikova, M. Biological activity and clinical implications of the matrix metalloproteinases. Anticancer Res. 2008, 28, 1389-1397. [PubMed]

66. Thakur, V.; Bedogni, B. The membrane tethered matrix metalloproteinase MT1-MMP at the forefront of melanoma cell invasion and metastasis. Pharmacol. Res. 2016, 111, 17-22. [CrossRef] [PubMed]

67. Wen, X.; Xiong, Y.; Jin, L.; Zhang, M.; Huang, L.; Mao, Y.; Zhou, C.; Qiao, Y.; Zhang, Y. Bisphenol A Exposure Enhances Endometrial Stromal Cell Invasion and Has a Positive Association with Peritoneal Endometriosis. Reprod. Sci. 2020, $27,704-712$. [CrossRef]

68. Chiappini, F.; Bastón, J.I.; Vaccarezza, A.; Singla, J.J.; Pontillo, C.; Miret, N.; Farina, M.; Meresman, G.; Randi, A. Enhanced cyclooxygenase-2 expression levels and metalloproteinase 2 and 9 activation by Hexachlorobenzene in human endometrial stromal cells. Biochem. Pharmacol. 2016, 109, 91-104. [CrossRef]

69. Yu, J.; Wang, Y.; Zhou, W.H.; Wang, L.; He, Y.Y.; Li, D.J. Combination of estrogen and dioxin is involved in the pathogenesis of endometriosis by promoting chemokine secretion and invasion of endometrial stromal cells. Hum. Reprod. 2008, 23, 1614-1626. [CrossRef]

70. Pan, H.; Zhang, P.; Li, J.R.; Wang, H.; Jin, M.F.; Feng, C.; Huang, H.F. c-Fos-Regulated Matrix Metalloproteinase-9 Expression is Involved in 17 $\beta$-Estradiol-Promoted Invasion of Human Endometrial Stromal Cell. Curr. Mol. Med. 2016, 16, 266-275. [CrossRef]

71. Zhang, L.; Xiong, W.; Li, N.; Liu, H.; He, H.; Du, Y.; Zhang, Z.; Liu, Y. Estrogen stabilizes hypoxia-inducible factor $1 \alpha$ through G protein-coupled estrogen receptor 1 in eutopic endometrium of endometriosis. Fertil. Steril. 2017, 107, 439-447. [CrossRef]

72. Xiong, W.; Zhang, L.; Xiong, Y.; Liu, H.; Liu, Y. Hypoxia Promotes Invasion of Endometrial Stromal Cells via Hypoxia-Inducible Factor $1 \alpha$ Upregulation-Mediated $\beta$-Catenin Activation in Endometriosis. Reprod. Sci. 2016, 23, 531-541. [CrossRef] [PubMed]

73. Liu, H.; Zhang, Z.; Xiong, W.; Zhang, L.; Xiong, Y.; Li, N.; He, H.; Du, Y.; Liu, Y. Hypoxia-inducible factor- $1 \alpha$ promotes endometrial stromal cells migration and invasion by upregulating autophagy in endometriosis. Reproduction 2017, 153, 809-820. [CrossRef] [PubMed]

74. Liu, H.; Zhang, Z.; Xiong, W.; Zhang, L.; Du, Y.; Liu, Y.; Xiong, X. Long non-coding RNA MALAT1 mediates hypoxia-induced pro-survival autophagy of endometrial stromal cells in endometriosis. J. Cell Mol. Med. 2019, 23, 439-452. [CrossRef]

75. Li, W.; Li, S.; Deng, L.; Yang, S.; Li, M.; Long, S.; Chen, S.; Lin, F.; Xiao, L. Decreased MT1-MMP in gastric cancer suppressed cell migration and invasion via regulating MMPs and EMT. Tumour Biol. 2015, 36, 6883-6889. [CrossRef] [PubMed]

76. Ding, C.; Luo, J.; Li, L.; Li, S.; Yang, L.; Pan, H.; Liu, Q.; Qin, H.; Chen, C.; Feng, J. Gab2 facilitates epithelial-to-mesenchymal transition via the MEK/ERK/MMP signaling in colorectal cancer. J. Exp. Clin. Cancer Res. 2016, 35, 5. [CrossRef]

77. Vos, M.C.; Hollemans, E.; Ezendam, N.; Feijen, H.; Boll, D.; Pijlman, B.; van der Putten, H.; Klinkhamer, P.; van Kuppevelt, T.H.; van der Wurff, A.A.; et al. MMP-14 and CD44 in Epithelial-to-Mesenchymal Transition (EMT) in ovarian cancer. J. Ovarian Res. 2016, 9, 53. [CrossRef]

78. Chen, C.M.; Lin, C.L.; Chiou, H.L.; Hsieh, S.C.; Lin, C.L.; Cheng, C.W.; Hung, C.H.; Tsai, J.P.; Hsieh, Y.H. Loss of endothelial cellspecific molecule 1 promotes the tumorigenicity and metastasis of prostate cancer cells through regulation of the TIMP-1/MMP-9 expression. Oncotarget 2017, 8, 13886-13897. [CrossRef] [PubMed]

79. Kalluri, R.; Neilson, E.G. Epithelial-mesenchymal transition and its implications for fibrosis. J. Clin. Investig. 2003, 112, 1776-1784. [CrossRef]

80. Thiery, J.P.; Acloque, H.; Huang, R.Y.; Nieto, M.A. Epithelial-mesenchymal transitions in development and disease. Cell 2009, 139, 871-890. [CrossRef]

81. Thiery, J.P.; Sleeman, J.P. Complex networks orchestrate epithelial-mesenchymal transitions. Nat. Rev. Mol. Cell Biol. 2006, 7, 131-142. [CrossRef] [PubMed] 
82. Wang, X.; Nie, J.; Zhou, Q.; Liu, W.; Zhu, F.; Chen, W.; Mao, H.; Luo, N.; Dong, X.; Yu, X. Downregulation of Par-3 expression and disruption of Par complex integrity by TGF-beta during the process of epithelial to mesenchymal transition in rat proximal epithelial cells. Biochim. Biophys. Acta 2008, 1782, 51-59. [CrossRef] [PubMed]

83. Karamanou, K.; Franchi, M.; Vynios, D.; Brézillon, S. Epithelial-to-mesenchymal transition and invadopodia markers in breast cancer: Lumican a key regulator. Semin. Cancer Biol. 2020, 62, 125-133. [CrossRef] [PubMed]

84. D'Amico, G.; Munoz-Felix, J.M.; Pedrosa, A.R.; Hodivala-Dilke, K.M. "Splitting the matrix": Intussusceptive angiogenesis meets MT1-MMP. EMBO Mol. Med. 2020, 12, e11663. [CrossRef]

85. Mazor, R.; Alsaigh, T.; Shaked, H.; Altshuler, A.E.; Pocock, E.S.; Kistler, E.B.; Karin, M.; Schmid-Schonbein, G.W. Matrix metalloproteinase-1-mediated up-regulation of vascular endothelial growth factor-2 in endothelial cells. J. Biol. Chem. 2013, 288, 598-607. [CrossRef] [PubMed]

86. Ito, T.K.; Ishii, G.; Saito, S.; Yano, K.; Hoshino, A.; Suzuki, T.; Ochiai, A. Degradation of soluble VEGF receptor-1 by MMP-7 allows VEGF access to endothelial cells. Blood 2009, 113, 2363-2369. [CrossRef]

87. Sang, Q.X. Complex role of matrix metalloproteinases in angiogenesis. Cell Res. 1998, 8, 171-177. [CrossRef]

88. Sood, D.; Cairns, D.M.; Dabbi, J.M.; Ramakrishnan, C.; Deisseroth, K.; Black, L.D., 3rd; Santaniello, S.; Kaplan, D.L. Functional maturation of human neural stem cells in a 3D bioengineered brain model enriched with fetal brain-derived matrix. Sci. Rep. 2019, 9, 17874. [CrossRef]

89. Noriega-Guerra, H.; Freitas, V.M. Extracellular Matrix Influencing HGF/c-MET Signaling Pathway: Impact on Cancer Progression. Int. J. Mol. Sci. 2018, 19, 3300. [CrossRef]

90. Vigano, P.; Candiani, M.; Monno, A.; Giacomini, E.; Vercellini, P.; Somigliana, E. Time to redefine endometriosis including its pro-fibrotic nature. Hum. Reprod. 2018, 33, 347-352. [CrossRef] [PubMed]

91. Kendziorski, J.A.; Belcher, S.M. Strain-specific induction of endometrial periglandular fibrosis in mice exposed during adulthood to the endocrine disrupting chemical bisphenol A. Reprod. Toxicol. 2015, 58, 119-130. [CrossRef]

92. Holmbeck, K.; Bianco, P.; Caterina, J.; Yamada, S.; Kromer, M.; Kuznetsov, S.A.; Mankani, M.; Robey, P.G.; Poole, A.R.; Pidoux, I.; et al. MT1-MMP-deficient mice develop dwarfism, osteopenia, arthritis, and connective tissue disease due to inadequate collagen turnover. Cell 1999, 99, 81-92. [CrossRef]

93. Matsuzaki, S.; Canis, M.; Pouly, J.L.; Darcha, C. Soft matrices inhibit cell proliferation and inactivate the fibrotic phenotype of deep endometriotic stromal cells in vitro. Hum. Reprod. 2016, 31, 541-553. [CrossRef]

94. Vallve-Juanico, J.; Houshdaran, S.; Giudice, L.C. The endometrial immune environment of women with endometriosis. Hum. Reprod. Update 2019, 25, 564-591. [CrossRef] [PubMed]

95. Sciezynska, A.; Komorowski, M.; Soszynska, M.; Malejczyk, J. NK Cells as Potential Targets for Immunotherapy in Endometriosis. J. Clin. Med. 2019, 8, 1468. [CrossRef] [PubMed]

96. Zhou, W.J.; Yang, H.L.; Shao, J.; Mei, J.; Chang, K.K.; Zhu, R.; Li, M.Q. Anti-inflammatory cytokines in endometriosis. Cell. Mol. Life Sci. 2019, 76, 2111-2132. [CrossRef] [PubMed]

97. Oosterlynck, D.J.; Meuleman, C.; Waer, M.; Vandeputte, M.; Koninckx, P.R. The natural killer activity of peritoneal fluid lymphocytes is decreased in women with endometriosis. Fertil. Steril. 1992, 58, 290-295. [CrossRef]

98. Rossi, G.R.; Trindade, E.S.; Souza-Fonseca-Guimaraes, F. Tumor Microenvironment-Associated Extracellular Matrix Components Regulate NK Cell Function. Front. Immunol. 2020, 11, 73. [CrossRef]

99. Shiraishi, K.; Mimura, K.; Kua, L.F.; Koh, V.; Siang, L.K.; Nakajima, S.; Fujii, H.; Shabbir, A.; Yong, W.P.; So, J.; et al. Inhibition of MMP activity can restore NKG2D ligand expression in gastric cancer, leading to improved NK cell susceptibility. J. Gastroenterol. 2016, 51, 1101-1111. [CrossRef] [PubMed]

100. Barber, D.F.; Faure, M.; Long, E.O. LFA-1 contributes an early signal for NK cell cytotoxicity. J. Immunol. 2004, 173, 3653-3659. [CrossRef] [PubMed]

101. Garcia-Gomez, E.; Vazquez-Martinez, E.R.; Reyes-Mayoral, C.; Cruz-Orozco, O.P.; Camacho-Arroyo, I.; Cerbon, M. Regulation of Inflammation Pathways and Inflammasome by Sex Steroid Hormones in Endometriosis. Front. Endocrinol. 2019, $10,935$. [CrossRef] [PubMed]

102. Wu, M.H.; Shoji, Y.; Wu, M.C.; Chuang, P.C.; Lin, C.C.; Huang, M.F.; Tsai, S.J. Suppression of matrix metalloproteinase-9 by prostaglandin E(2) in peritoneal macrophage is associated with severity of endometriosis. Am. J. Pathol. 2005, 167, 1061-1069. [CrossRef]

103. Zhu, M.; Yang, M.; Yang, Q.; Liu, W.; Geng, H.; Pan, L.; Wang, L.; Ge, R.; Ji, L.; Cui, S.; et al. Chronic Hypoxia-Induced Microvessel Proliferation and Basal Membrane Degradation in the Bone Marrow of Rats Regulated through the IL-6/JAK2/STAT3/MMP-9 Pathway. BioMed Res. Int. 2020, 2020, 9204708. [CrossRef] [PubMed]

104. Wang, X.; Fan, J.; Ding, X.; Sun, Y.; Cui, Z.; Liu, W. Tanshinone I Inhibits IL-1beta-Induced Apoptosis, Inflammation And Extracellular Matrix Degradation In Chondrocytes CHON-001 Cells And Attenuates Murine Osteoarthritis. Drug Des. Dev. Ther. 2019, 13, 3559-3568. [CrossRef]

105. Meola, J.; Rosa e Silva, J.C.; Dentillo, D.B.; da Silva, W.A., Jr.; Veiga-Castelli, L.C.; Bernardes, L.A.; Ferriani, R.A.; de Paz, C.C.; Giuliatti, S.; Martelli, L. Differentially expressed genes in eutopic and ectopic endometrium of women with endometriosis. Fertil. Steril. 2010, 93, 1750-1773. [CrossRef] [PubMed]

106. Malvezzi, H.; Aguiar, V.G.; Paz, C.C.; Tanus-Santos, J.E.; Penna, I.A.; Navarro, P.A. Increased circulating MMP-2 levels in infertile patients with moderate and severe pelvic endometriosis. Reprod. Sci. 2013, 20, 557-562. [CrossRef] 
107. Cho, Y.J.; Kim, N.H.; Jeong, K.A.; Lee, J.Y.; Moon, H.S.; Kim, H.L.; Chung, H.W. Association between MMP-2 and TIMP-2 gene polymorphisms and advanced-stage endometriosis in Korean women. Am. J. Reprod. Immunol. 2013, 69, 73-84. [CrossRef] [PubMed]

108. Wu, T.; Zhang, R.; Jiang, Q.; Li, Z.; Wu, R. Expression of cellular adherent and invasive molecules in recurrent ovarian endometriosis. J. Int. Med. Res. 2020, 48, 300060520971993. [CrossRef]

109. Gambadauro, P.; Carli, V.; Hadlaczky, G. Depressive symptoms among women with endometriosis: A systematic review and meta-analysis. Am. J. Obstet. Gynecol. 2019, 220, 230-241. [CrossRef]

110. Bedaiwy, M.A.; Alfaraj, S.; Yong, P.; Casper, R. New developments in the medical treatment of endometriosis. Fertil. Steril. 2017, 107, 555-565. [CrossRef]

111. Arkadash, V.; Yosef, G.; Shirian, J.; Cohen, I.; Horev, Y.; Grossman, M.; Sagi, I.; Radisky, E.S.; Shifman, J.M.; Papo, N. Development of High Affinity and High Specificity Inhibitors of Matrix Metalloproteinase 14 through Computational Design and Directed Evolution. J. Biol. Chem. 2017, 292, 3481-3495. [CrossRef] [PubMed]

112. Ager, E.I.; Kozin, S.V.; Kirkpatrick, N.D.; Seano, G.; Kodack, D.P.; Askoxylakis, V.; Huang, Y.; Goel, S.; Snuderl, M.; Muzikansky, A.; et al. Blockade of MMP14 activity in murine breast carcinomas: Implications for macrophages, vessels, and radiotherapy. J. Natl. Cancer Inst. 2015, 107, djv017. [CrossRef]

113. Goffin, L.; Fagagnini, S.; Vicari, A.; Mamie, C.; Melhem, H.; Weder, B.; Lutz, C.; Lang, S.; Scharl, M.; Rogler, G.; et al. Anti-MMP-9 Antibody: A Promising Therapeutic Strategy for Treatment of Inflammatory Bowel Disease Complications with Fibrosis. Inflamm. Bowel Dis. 2016, 22, 2041-2057. [CrossRef] [PubMed]

114. Shah, M.A.; Starodub, A.; Sharma, S.; Berlin, J.; Patel, M.; Wainberg, Z.A.; Chaves, J.; Gordon, M.; Windsor, K.; Brachmann, C.B.; et al. Andecaliximab/GS-5745 Alone and Combined with mFOLFOX6 in Advanced Gastric and Gastroesophageal Junction Adenocarcinoma: Results from a Phase I Study. Clin. Cancer Res. 2018, 24, 3829-3837. [CrossRef]

115. Vandenbroucke, R.E.; Libert, C. Is there new hope for therapeutic matrix metalloproteinase inhibition? Nat. Rev. Drug Discov. 2014, 13, 904-927. [CrossRef] [PubMed]

116. Falardeau, P.; Champagne, P.; Poyet, P.; Hariton, C.; Dupont, E. Neovastat, a naturally occurring multifunctional antiangiogenic drug, in phase III clinical trials. Semin. Oncol. 2001, 28, 620-625. [CrossRef]

117. Latreille, J.; Batist, G.; Laberge, F.; Champagne, P.; Croteau, D.; Falardeau, P.; Levinton, C.; Hariton, C.; Evans, W.K.; Dupont, E. Phase I/II trial of the safety and efficacy of AE-941 (Neovastat) in the treatment of non-small-cell lung cancer. Clin. Lung Cancer 2003, 4, 231-236. [CrossRef]

118. Sharpe-Timms, K.L.; Zimmer, R.L.; Jolliff, W.J.; Wright, J.A.; Nothnick, W.B.; Curry, T.E. Gonadotropin-releasing hormone agonist (GnRH-a) therapy alters activity of plasminogen activators, matrix metalloproteinases, and their inhibitors in rat models for adhesion formation and endometriosis: Potential GnRH-a-regulated mechanisms reducing adhesion formation. Fertil. Steril. 1998, 69, 916-923. [CrossRef]

119. Woo, J.H.; Ahn, J.H.; Jang, D.S.; Choi, J.H. Effect of Dehydrocostus Lactone Isolated from the Roots of Aucklandia lappa on the Apoptosis of Endometriotic Cells and the Alternative Activation of Endometriosis-Associated Macrophages. Am. J. Chin. Med. 2019, 47, 1289-1305. [CrossRef]

120. Li, Z.; Liu, H.; He, Z.; Zhang, G.; Lang, J. Effects of cisplatin and letrozole on surgically induced endometriosis and comparison of the two medications in a rat model. Eur. J. Pharm. Sci. 2016, 93, 132-140. [CrossRef]

121. Hu, F.; Hu, Y.; Peng, F. Synergistic and protective effect of atorvastatin and amygdalin against histopathological and biochemical alterations in Sprague-Dawley rats with experimental endometriosis. AMB Express 2019, 9, 37. [CrossRef] [PubMed]

122. Chen, Y.; Wei, J.; Zhang, Y.; Sun, W.; Li, Z.; Wang, Q.; Xu, X.; Li, C.; Li, P. Anti-endometriosis Mechanism of Jiawei Foshou San Based on Network Pharmacology. Front. Pharmacol. 2018, 9, 811. [CrossRef] [PubMed]

123. Kapoor, R.; Sirohi, V.K.; Gupta, K.; Dwivedi, A. Naringenin ameliorates progression of endometriosis by modulating Nrf2/Keap1/HO1 axis and inducing apoptosis in rats. J. Nutr. Biochem. 2019, 70, 215-226. [CrossRef]

124. Wei, X.; Shao, X. Nobiletin alleviates endometriosis via down-regulating NF-kappaB activity in endometriosis mouse model. Biosci. Rep. 2018, 38, BSR20180470. [CrossRef]

125. Machado, D.E.; Rodrigues-Baptista, K.C.; Alessandra-Perini, J.; Soares de Moura, R.; Santos, T.A.; Pereira, K.G.; Marinho da Silva, Y.; Souza, P.J.; Nasciutti, L.E.; Perini, J.A. Euterpe oleracea Extract (Acai) Is a Promising Novel Pharmacological Therapeutic Treatment for Experimental Endometriosis. PLoS ONE 2016, 11, e0166059. [CrossRef]

126. Samartzis, E.P.; Fink, D.; Stucki, M.; Imesch, P. Doxycycline reduces MMP-2 activity and inhibits invasion of $12 Z$ epithelial endometriotic cells as well as MMP-2 and -9 activity in primary endometriotic stromal cells in vitro. Reprod. Biol. Endocrinol. 2019, 17, 38. [CrossRef] [PubMed]

127. Kim, J.H.; Woo, J.H.; Kim, H.M.; Oh, M.S.; Jang, D.S.; Choi, J.H. Anti-Endometriotic Effects of Pueraria Flower Extract in Human Endometriotic Cells and Mice. Nutrients 2017, 9, 212. [CrossRef]

128. Kim, J.H.; Yang, Y.I.; Ahn, J.H.; Lee, J.G.; Lee, K.T.; Choi, J.H. Deer (Cervus elaphus) antler extract suppresses adhesion and migration of endometriotic cells and regulates MMP-2 and MMP-9 expression. J. Ethnopharmacol. 2012, 140, 391-397. [CrossRef]

129. Kiykac Altinbas, S.; Tapisiz, O.L.; Cavkaytar, S.; Simsek, G.; Oguztuzun, S.; Goktolga, U. Is montelukast effective in regression of endometrial implants in an experimentally induced endometriosis model in rats? Eur. J. Obstet. Gynecol. Reprod. Biol. 2015, 184, 7-12. [CrossRef] 
130. Jana, S.; Rudra, D.S.; Paul, S.; Snehasikta, S. Curcumin delays endometriosis development by inhibiting MMP-2 activity. Indian J. Biochem. Biophys. 2012, 49, 342-348.

131. Miyashita, M.; Koga, K.; Izumi, G.; Sue, F.; Makabe, T.; Taguchi, A.; Nagai, M.; Urata, Y.; Takamura, M.; Harada, M.; et al. Effects of 1,25-Dihydroxy Vitamin D3 on Endometriosis. J. Clin. Endocrinol. Metab. 2016, 101, 2371-2379. [CrossRef] [PubMed] 